\title{
PROPOSAL OF A SET OF INDICATORS FOR SUSTAINABILITY EVALUATION OF FOOD PRODUCTION IN AN URBAN CONTEXT
}

\author{
MARCIO ALEXANDRE ALBERTI ${ }^{1}$, ILEANA BLANCO ${ }^{2}$, GIULIANO VOX ${ }^{1}$, \\ LUCIENE PIMENTEL DA SILVA ${ }^{3} \&$ EVELIA SCHETTINI $^{1}$ \\ ${ }^{1}$ Department of Agricultural and Environmental Science DISAAT, University of Bari, Italy \\ ${ }^{2}$ Department of Biological and Environmental Sciences and Technologies DiSTeBA, University of Salento, Italy \\ ${ }^{3}$ Post Graduation Program in Environmental Science, Rio de Janeiro State University, Brazil
}

\begin{abstract}
Urban agriculture (UA) is steadily gaining supporters worldwide, and this is partly because constantly growing urban populations recognize the need to increase food production and promote a healthy diet. UA can also generate extra income, promote socialization leading to valorisation of urban areas. Nevertheless, UA faces several challenges, including limited available space, stressed natural resources, pollution in a context characterized by climate change and new consumption patterns. At the same time, if UA is practiced in the same way as other forms of agriculture, it may have some undesirable environmental impacts on urban areas. The use of indicators can provide decision makers with a tool to evaluate the sustainable insertion of agriculture in cities. This work aims to propose a minimum set of indicators as the basis for an index to assess progress of urban vegetable production towards sustainability. Nineteen urban sustainability indexes, composed of several indicators founded in the literature and already used by several institutions, were analysed. These indexes were broken down into a set of 1579 indicators. Analysis of the relevancy to issues such as food, energy, water, land and pollution, and the selection based on the criteria of being measurable, sensitive to stress, predictable, anticipatory, controllable, integrative, responsive and stable, led to a 26 basic indicators selection. These are proposed as the basis for an innovative UA sustainability index. This will be built based on the Delphi method and is intended to support communities in establishing sustainable and resilient cities.
\end{abstract}

Keywords: urban agriculture, vegetables, NEXUS, food, energy, water, land use, pollution.

\section{INTRODUCTION}

Urban agriculture (UA) can be defined as "farming operations taking place in and around the city that beyond food production provides environmental services (soil, water and climate protection; resource efficiency; biodiversity), social services (social inclusion, education, health, leisure, cultural heritage) and supports local economies by a significant direct urban market orientation" [1]. UA initiatives are highly articulated to many of the 2030 UN 17 sustainable development goals (SDGs) [2]. These have been adopted by non-governmental organizations and public administrators as a sustainable and ecologically correct solution to the problems of food security, job and income generation in the metropolis. UA has gained even more support in the context of urban heat island mitigation and climate change, as a direct contribution towards adaptive management. Food production within UA also provides a number of benefits such as the reduction of emissions related to food transport, improvement in the nutritional level of the population, and the use of rainwater. UA can also contribute to the spread of Sustainable Urban Drainage Systems (SuDS) in the context of sustainable drainage as in nature-based solutions, sponge cities, and blue-green cities.

Agriculture is a topic inextricably linked with water, energy and land use. Factors that cannot be approached separately, such as food production, water, energy and land use, are studied jointly in what several world organizations refer to as the "nexus" approach [3]. Nexus 
approaches are conceptions and initiatives introduced, preferably transversely, to achieve an ecological and circular economy, allowing actions aimed at investing in the conservation of ecosystem services, creating more with less, and accelerating the social and economic improvement of excluded groups by promoting the inclusion of poorer populations [4].

However, as with other forms of agriculture, UA can harm the environment, and naturally requires more water, energy, and space within an already crowded metropolis, where natural resources are often already stressed. UA must be developed while respecting the local capacity to achieve sustainability. "Indicators" are tools that can provide an early warning of problems and allow adequate preventive action [5]. These are widely used in understanding, monitoring and managing complex systems where simplification is required, such as an urbanized area or a natural ecosystem [6]. An ecological indicator is a simplification of the complex ecosystem and interlinkages, which has a wide application in the development of policies, plans and programs related to the environment and ecology via measurement processes, allowing assessment of progress toward sustainable development [7].

Numerous government and private institutions are working on urban sustainability indicators, but few instruments able to measure and assess progress towards the sustainability of food production in cities are available in the literature, and these are often scattered and difficult to access [8]. This work assumes that sustainable UA (target situation) can produce food for all the inhabitants of a city by using available local resources (water, energy, land), without harming the natural flows of resources and without contaminating the environment. Many authors also assume that UA will provide only certain kinds of food for population needs [9], [10]. However, UA may also involve cultivations that adapt well to small spaces and often to alternative cultivation areas, such as roofs, walls, underground galleries or indoor environments in buildings [11]. UA can take advantage of producing foods with high market value and productivity, such as vegetables.

This study aimed to propose a minimum set of indicators as the basis for creating an index to assess the progress of urban vegetable production towards sustainability. This is part of a wider research project aimed at defining an index based on this set of indicators of sustainability for urban vegetable production. The intention is that this index will be formulated in the future using the Delphi method, involving the consultation of specialists in this field. They will be questioned about the suitability of the proposed indicators, and about the relative importance of each one, and this will be taken into account in the different weighting of each indicator in the formulation of the index.

\section{MATERIAL AND METHODS}

The present work was based on a conceptual framework of three levels of selection, which aimed to identify a set of basic indicators (also called concrete or specific indicators) able to assess progress toward sustainable UA. A group of indexes used by the international community to assess urban sustainability was identified in the scientific and technical literature as the source for proposing the indicators to constitute an index for assessment of the sustainability of these UA systems.

We mainly used a set of indexes gathered in the European Commission report entitled "In-depth Report - Indicators for Sustainable Cities" [12]. The indexes were analysed and broken down into a list of basic indicators. This initial group evaluates various aspects related to urban development such as quality of life, water management, climate change, housing, transportation, risk resilience and the entire food system. The list includes 15 sustainable indexes developed by institutions in Europe, China and the USA, and by supranational institutions, such as the World Bank, the United Nations and Local Governments for 
Sustainability - ICLEI (a group of more than 1,750 local and regional governments engaged in sustainable urban development).

Four additional indexes were identified in the literature and these were added to the set of indexes collected by the European Commission: "The City Region Food System" [13] and "The Milan Urban Food Policy Pact" [14], both related to the whole food systems; a conceptual framework from SUSFAN, a team of European experts on sustainable food and nutrition security, which developed a set of concepts, metrics and tools for helping policy and decision makers assess the progress towards goals related to the EU food system [15]; and the SDGs from the UN [2]. The complete list of 19 indexes and a description of the relative features of each one is shown in Table 1.

Table 1: List of urban and food production sustainability indexes.

\begin{tabular}{|c|c|c|c|}
\hline $\begin{array}{l}\text { Sustainability } \\
\text { indexes }\end{array}$ & NI & Indicators' main areas & Subject of assessment \\
\hline $\begin{array}{l}1-\text { China Urban } \\
\text { Sustainability Index } \\
\text { (USI 2013) [12] }\end{array}$ & 23 & Society, Environment, Economy & $\begin{array}{l}\text { Quality of life } \\
\text { (Benchmark = New } \\
\text { York) }\end{array}$ \\
\hline $\begin{array}{l}2-\text { City Blueprint } \\
{[16]}\end{array}$ & 24 & $\begin{array}{l}\text { Human wellbeing, Environment, } \\
\text { Economic wellbeing }\end{array}$ & $\begin{array}{l}\text { Urban water } \\
\text { management (quick } \\
\text { scan and baseline } \\
\text { assessment) }\end{array}$ \\
\hline $\begin{array}{l}3-\text { Blue City Index } \\
\left(\mathrm{BCI}^{*}\right)[17]\end{array}$ & 25 & $\begin{array}{l}\text { Water quality, Solid waste } \\
\text { treatment, Basic water services, } \\
\text { Wastewater treatment, } \\
\text { Infrastructure, Robustness, } \\
\text { Governance }\end{array}$ & $\begin{array}{l}\text { Urban water } \\
\text { management (quick } \\
\text { scan and baseline } \\
\text { assessment) }\end{array}$ \\
\hline $\begin{array}{l}4-\text { European } \\
\text { Green Capital } \\
\text { Award [12] }\end{array}$ & 12 & $\begin{array}{l}\text { Green growth and } \\
\text { eco-innovation, Sustainable land } \\
\text { use, Waste management, } \\
\text { Sustainable urban mobility }\end{array}$ & $\begin{array}{l}\text { Improvement of the } \\
\text { urban environment and } \\
\text { progress towards } \\
\text { healthier and } \\
\text { sustainable living areas }\end{array}$ \\
\hline $\begin{array}{l}5-\text { Green City } \\
\text { Index [18] }\end{array}$ & 30 & $\begin{array}{l}\mathrm{CO}_{2} \text { emissions, Energy, } \\
\text { buildings, Land use, Transport, } \\
\text { water and sanitation, Waste } \\
\text { management, Air quality and } \\
\text { Environmental governance }\end{array}$ & $\begin{array}{l}\text { Environmental } \\
\text { performance }\end{array}$ \\
\hline $\begin{array}{l}\text { 6- Global City } \\
\text { Indicators Program } \\
\text { (Facility) [19] }\end{array}$ & 115 & City services, Quality of life & $\begin{array}{l}\text { City governance, City } \\
\text { services and quality } \\
\text { of life }\end{array}$ \\
\hline $\begin{array}{l}7-\text { Global City } \\
\text { Indicator - ISO } \\
37120[20]\end{array}$ & 128 & $\begin{array}{l}\text { Education, Energy, Transport, } \\
\text { Health, Water management }\end{array}$ & $\begin{array}{l}\text { Smartness and } \\
\text { resilience }\end{array}$ \\
\hline $\begin{array}{l}8-\text { Indicators for } \\
\text { Sustainability [21] }\end{array}$ & 32 & Economy, Environment, Social & $\begin{array}{l}\text { City progress toward } \\
\text { sustainability }\end{array}$ \\
\hline $\begin{array}{l}9 \text { - Reference } \\
\text { Framework for } \\
\text { Sustainable Cities } \\
\text { (RFSC-v3) [22] }\end{array}$ & 30 & $\begin{array}{l}\text { Spatial dimension, Governance, } \\
\text { Society and culture, Economy, } \\
\text { Environment }\end{array}$ & $\begin{array}{l}\text { Project/program of } \\
\text { sustainability }\end{array}$ \\
\hline
\end{tabular}


Table 1: Continued.

\begin{tabular}{|c|c|c|c|}
\hline $\begin{array}{l}\text { Sustainability } \\
\text { indexes }\end{array}$ & NI & Indicators' main areas & Subject of assessment \\
\hline $\begin{array}{l}10-\text { STAR (2.0)- } \\
\text { (Sustainability } \\
\text { Tools for Assessing } \\
\text { and Rating } \\
\text { Communities) [23] }\end{array}$ & 49 & $\begin{array}{l}\text { Built environment, Climate and } \\
\text { energy, Economy and jobs, } \\
\text { Education and arts, Equity, } \\
\text { empower, health and safety, } \\
\text { Natural systems, innovation and } \\
\text { process }\end{array}$ & $\begin{array}{l}\text { Economic, } \\
\text { environmental and } \\
\text { social aspects }\end{array}$ \\
\hline $\begin{array}{l}11-\text { Urban Audit } \\
{[12]}\end{array}$ & 333 & $\begin{array}{l}\text { Demography, Social aspects, } \\
\text { Economic aspects, Civic } \\
\text { involvement, training and } \\
\text { education, Environment, travel } \\
\text { and transport, Information, } \\
\text { society, culture and recreation }\end{array}$ & Life quality \\
\hline $\begin{array}{l}12-\text { Urban } \\
\text { Ecosystem Europe } \\
{[24]}\end{array}$ & 25 & $\begin{array}{l}\text { Health, Consumption, Mobility, } \\
\text { energy and climate change, } \\
\text { Social equity, Governance }\end{array}$ & $\begin{array}{l}\text { Environmental } \\
\text { sustainability and } \\
\text { climate change }\end{array}$ \\
\hline $\begin{array}{l}13-\text { Urban } \\
\text { Metabolism } \\
\text { Framework [25] }\end{array}$ & 15 & $\begin{array}{l}\text { Urban flows, Urban patterns, } \\
\text { Urban drivers, Urban quality }\end{array}$ & $\begin{array}{l}\text { The sustainability of a } \\
\text { city }\end{array}$ \\
\hline $\begin{array}{l}14 \text { - Index of urban } \\
\text { sustainability } \\
\text { performance }[26]\end{array}$ & 16 & Society, Environment, Economy & $\begin{array}{l}\text { Economic, } \\
\text { environmental and } \\
\text { socio-cultural progress }\end{array}$ \\
\hline $\begin{array}{l}15-\text { Habitat } \\
\text { Agenda Indicators } \\
{[27]}\end{array}$ & 42 & $\begin{array}{l}\text { Land, Social development } \\
\text { and eradication of } \\
\text { poverty, Environmental } \\
\text { management, Economic } \\
\text { development, Governance }\end{array}$ & $\begin{array}{l}\text { Cities without Slum - } \\
\text { commitment to the } \\
\text { world's poor }\end{array}$ \\
\hline $\begin{array}{l}16 \text { - Sustainable } \\
\text { Development } \\
\text { Goals [2] }\end{array}$ & 232 & $\begin{array}{l}\text { Human factor, Food security, } \\
\text { Water, Energy, Infrastructures }\end{array}$ & $\begin{array}{l}\text { Achievement of } 2030 \\
\text { Agenda for Sustainable } \\
\text { Development } \\
\text { objectives }\end{array}$ \\
\hline $\begin{array}{l}17-\text { City Region } \\
\text { Food System [13] }\end{array}$ & 210 & $\begin{array}{l}\text { Food security, Economy, Natural } \\
\text { resources, Social aspects }\end{array}$ & $\begin{array}{l}\text { Whole food system, } \\
\text { from production to } \\
\text { waste, food system } \\
\text { policy and planning. }\end{array}$ \\
\hline $\begin{array}{l}18-\text { MILAN } \\
\text { PACT [14] }\end{array}$ & 42 & $\begin{array}{l}\text { Governance, Sustainable diets } \\
\text { and nutrition, Social and } \\
\text { economics equity, Food } \\
\text { production, Food supply and } \\
\text { distribution, Food waste }\end{array}$ & $\begin{array}{l}\text { Whole food system, } \\
\text { from production to } \\
\text { final consumer }\end{array}$ \\
\hline 19 - SUSFAN [15] & 196 & $\begin{array}{l}\text { Food, Environment, Economy, } \\
\text { Human factor }\end{array}$ & $\begin{array}{l}\text { Whole food system, } \\
\text { from production to } \\
\text { final consumer }\end{array}$ \\
\hline
\end{tabular}

(NI) number of basic indicators used in the INDEX. 
The first selection was made by considering the relationship of each basic indicator with at least one component of the Nexus Food-Energy-Water-Land Use-Pollution. This includes environmental, economic and social criteria. We defined this Nexus, inspired by the following: Food-Energy-Water (FEW) [28], Water-Energy-Land-Food (WELF) [29], Ecosystems-Water-Food-Land-Energy (EWFLE) [30] and Energy-Water-Pollution [31] Nexus. Moreover, redundant indicators or those unrelated to UA were removed.

Urban indicators linked to safety, governance, public policy, culture, sport and recreation were not considered in the context of UA and food production. Transport indicators were not considered either, since one benefit of urban agriculture is to produce food locally, thus reducing transport costs ("zero miles food").

A second selection was made according to the recurrence of the indicator (or its variants) in the 19 first selected indexes, so that we selected the basic indicators considered by at least two sustainability indexes.

This second set of potential indicators/indexes underwent a third selection process. This selection required indicators to have certain "individual qualities", i.e. they must be measurable, sensitive to stress, predictable, anticipatory, controllable, integrative, responsive and stable [32], [33].

\section{RESULTS AND DISCUSSION}

The breakdown process performed on the 19 indexes for assessment of urban sustainability resulted in a set of 1579 basic indicators.

The first selection, concerning relevancy to the "Nexus" and to UA, gave 512 basic indicators. In order to facilitate this study phase, the Nexus categories were split into 9 sub-categories, as illustrated by the first two columns of Table 2. Food was split into food production characteristics, and human factors, including work to produce food and the socio-economic conditions that influence this (education level and income level). The energy category was sub-divided into energy source and $\mathrm{CO}_{2}$ emission. Water was sub-divided into water sources and effluent issues. Land-use was sub-divided into a "characteristics" group that aggregates space-related indicators, like soil occupation and use (built up area ratio, green space, disposable agriculture area), and another group that addressed residues/waste issues (waste collection and recycling ratio). Finally, pollution was sub-divided into three sub-categories: air, water and soil. Since there were already two special sub-categories to group indicators regarding water (sources and effluents), and no basic indicator met the requirements of considering soil pollution, it was established that pollution would be linked only to indicators that affect air quality (Table 2).

The second selection concerning indicator recurrence in the indexes reduced the number of indicators to 102 .

The third and final selection involved all the indicators which possessed all the individual qualities. This resulted in 26 indicators, as shown in Table 2, which also shows the metric units for each indicator.

Knowledge of food production is necessary in relation to the target of self-sufficiency for the local population in terms of the recommended daily intake of $300 \mathrm{~g}$ of vegetables per person per day [34]. Total local production of vegetables is given in tons/period. The adoption of a food production system that uses natural fertilizers (possibly by recycling the city's organic waste) and natural pest and disease controls would favour UA sustainability. The fraction of local production of vegetables produced without chemicals is given as a ratio of the total. 
Table 2: Selected basic indicators for sustainability evaluation of food production in an urban context.

\begin{tabular}{|c|c|c|c|c|}
\hline Category & Sub-category & N. & Basic indicator & Unity \\
\hline \multirow{9}{*}{ Food } & \multirow[b]{2}{*}{ Production } & 1 & Total vegetable production & tons/time \\
\hline & & 2 & $\begin{array}{l}\text { Total vegetable production without } \\
\text { chemicals }\end{array}$ & $\%$ \\
\hline & \multirow{7}{*}{ Human factor } & 3 & Human Development Index (HDI) & - \\
\hline & & 4 & Income commitments on food & $\%$ \\
\hline & & 5 & Unemployment rate & $\%$ \\
\hline & & 6 & Gini Index & \\
\hline & & 7 & $\begin{array}{l}\text { Residential/Individual Internet } \\
\text { access }\end{array}$ & $\%$ \\
\hline & & 8 & Adult illiteracy & $\%$ \\
\hline & & 9 & $\begin{array}{l}\text { Obesity incidence on } \\
\text { childhood/population }\end{array}$ & $\%$ \\
\hline \multirow{4}{*}{ Energy } & \multirow{3}{*}{ Sources } & 10 & $\begin{array}{l}\text { Residential /individual energy } \\
\text { consumption }\end{array}$ & $\mathrm{kWh} / \mathrm{cap}$ \\
\hline & & 11 & Energy price & $\mathrm{US} \$ / \mathrm{kWh}$ \\
\hline & & 12 & Energy green source ratio & $\%$ \\
\hline & $\mathrm{CO}_{2}$ emission & 13 & $\begin{array}{l}\text { Emission } \mathrm{CO}_{2} \text { equivalent per } \\
\text { habitant }\end{array}$ & $\mathrm{tCO}_{2} / \mathrm{cap}$ \\
\hline \multirow{7}{*}{ Water } & \multirow{5}{*}{ Source } & 14 & Annual Rainfall & $\mathrm{mm}$ \\
\hline & & 15 & $\begin{array}{l}\text { Residential/individual water } \\
\text { consumption }\end{array}$ & $\mathrm{L} /$ day/cap \\
\hline & & 16 & Water access rate & $\%$ \\
\hline & & 17 & $\begin{array}{l}\text { Water quality (Incidence of Non- } \\
\text { Standard Total Coliform Analysis) }\end{array}$ & $\%$ \\
\hline & & 18 & Public water supply price & $\mathrm{US} \$ / \mathrm{m}^{3}$ \\
\hline & \multirow[t]{2}{*}{ Effluents } & 19 & $\begin{array}{l}\text { Population served by wastewater } \\
\text { collection }\end{array}$ & $\%$ \\
\hline & & 20 & Sewage treatment & $\%$ \\
\hline \multirow{5}{*}{ Land use } & \multirow{3}{*}{ Characteristics } & 21 & Land tenure ratio & $\%$ \\
\hline & & 22 & Protected green space & $\%$ \\
\hline & & 23 & Undeveloped land use ratio & $\%$ \\
\hline & \multirow[t]{2}{*}{ Waste } & 24 & $\begin{array}{l}\text { Population served by regular solid } \\
\text { waste collection }\end{array}$ & $\%$ \\
\hline & & 25 & Municipal waste recycling & $\%$ \\
\hline Pollution & Air & 26 & $\begin{array}{l}\text { Exceedance of air quality standards } \\
\text { in urban areas }\end{array}$ & day/year \\
\hline
\end{tabular}

The Human Development Index (HDI) reflects the per capita income level, education and life expectancy of a given population. Although there is a strong correlation between wealth and good performance in sustainability indexes [18], Moran et al. [35] found that countries with higher incomes have greatly improved their HDI at the expense of a larger 
Ecological Footprint, while poorer countries have developed sufficiently without harming the environment, thus pointing to an inconsistency between HDI improvement and sustainable development.

The indicators "Income commitments on food" and "Unemployment rate" are basic indicators intrinsically linked to sustainable food production within the city. Data reveal that the poorest classes spend up to $85 \%$ of their income on food [36].

The Gini index is proposed as an indicator for the category of food. It is a measurement of income inequality, which ranges from 0 (perfect equality) to 1 (maximum inequality). In many countries that well performed on Gross Domestic Product (GDP), it is actually concentrated in a small sector of the population. The Gini coefficient offers a more balanced view of the progress required for an entire population to reach the target of self-reliance in vegetables established in this study.

Factors influencing the effectiveness and speed of project development are the ratio of access to the web, and illiteracy. Access to the web is essential for the development of smart cities, where the use of technologies based on the Internet of Things (IoT) will help to save energy, making traditional production processes more efficient and cities more resilient to climate change [37]. The web can be used to access new knowledge and technologies, to acquire inputs and to commercialize products.

Illiteracy can contribute to the unsustainability of UA. Nchanji et al. [38] described a case study from Northern Ghana on local government's distribution of pesticides for use on the region's crops. Since most urban farmers were illiterate, they were unable to read the instructions on the packaging labels, and used pesticides inappropriately, thereby contaminating themselves and the environment.

Obesity is an important quality indicator linked to the food factor of the Nexus. Although it does not reflect the lack of access to calories, obesity reflects access to low quality calories, which is often due to the lack of economic power to acquire calories and/or the existence of "food deserts", and UA has the potential to diversify and improve the diets of urban citizens [39]. Borges et al. [40] identified inequalities in the geographical distribution of food retailers in Jundiaí city, Brazil, which commercialize healthy and/or unhealthy foods. Local production via UA could improve the situation of many poor city areas with limited access to adequate food at affordable prices.

Concerning the category of energy, Schnell [41] and Eigenbrod and Gruda [42] have pointed out that factors such as off-season production and the low scale of urban production require higher energy use for food production. The higher demand for energy could be met by using alternative green energy sources, such as solar power, wind, geothermal and biomass. Therefore, it is fundamentally important to use indicators that quantify the total consumption of households, energy pricing and alternative energy use in the total energy matrix of a community.

With regard to emissions, the use of food production technologies is highly dependent on energy in cities at high latitudes or in desert areas. Greenhouses with heating or cooling systems can have a negative impact on the environment and thus overshadow the benefits of zero miles food [43]. Indicators that measure the amount of $\mathrm{CO}_{2}$ released into the environment per inhabitant can reflect the extent to which societies and their related activities are (or are not) dependent on non-renewable energy [44]

Annual rainfall is an indicator related to the most sustainable source of water for agriculture. This has become a critical factor in a changing climate, since a change in rainfall patterns has been observed in many cities, with more intense and longer spells of rain [45]. Lupia et al. [46] have demonstrated that some of the UA developed in Rome could be supplied by rainwater collected from roofs. The use of indicators related to water quality is 
just as important as those related to water availability. Water contaminated by chemical or biological agents used in the irrigation of fruits and vegetables (mainly those that are consumed raw) are important vectors of disease among the population [47].

Use of the public water supply can be the safest source, sometimes the only/easiest one, for the irrigation of vegetables in urban areas. However, it can be a criticality in cities that are reaching their maximum supply capacity, and many cities already have problems with network leakages accounting for up to $40 \%$ of the total. There is also the problem involved with the management of waste and effluents. The inclusion of indicators regarding household access to a piped public water supply, inhabitants' consumption and water prices are justified in a future sustainability Index.

Regarding space, land ownership plays a key role in UA. Most of the ground surface in cities is covered or sealed by buildings, roads or pavements [48], so that new agricultural production systems are required in order to adapt to the built areas. In addition, urban land tends to be "super" valued. The need to pay for tenure is also a key issue for the sustainability of UA projects. In addition, land does not necessarily consist of fertile soil, and this is another production factor for UA. The ratio of protected green space can be interpreted as an important sustainability indicator, since these green areas offer important environmental services that indirectly favour UA [49]. Another possibly good indicator is the amount of undeveloped land that could be cultivated, showing the feasibility of using these spaces for UA, although many urban areas may have problems such as heavy metal contamination of the soil.

However, contaminated sites may not be totally compromised, since many works point to bioremediation of these soils with the addition of organic matter and phosphates, or even substitution of the more superficial soil layers for the production of short root vegetables. The use of hydroponic crops (or other soilless production) also enables agricultural production in degraded urban areas [50], [51].

In developing countries, a considerable portion of the population lives in slum areas, where the lack of land regularization impedes the development of sustainable agriculture. Lack of a sense of ownership leads to the development of a predatory and low-investment type of agriculture onsite, with no concern for soil or water protection techniques that ensure the continuation of farming activity over time [52].

Urban and peri-urban spaces are affected by the deposition of residential waste. Indicators reflecting the percentage of the population served by regular waste collection services and the recycling percentage may show whether a community is reducing its production of waste. These are measures that favour sustainable development. Yates and Gutberlet [53] recall that use of the organic fraction of urban waste generates the recirculation of nutrients and reduces the production of methane, a greenhouse gas.

Finally, another important input for sustainable UA would be an atmosphere free of contaminating agents. Amato-Lourenço et al. [54] detected air pollutants deposited on the leaves of vegetables grown in an urban environment and showed that higher concentrations of heavy metals were correlated with the presence of traffic in the surrounding area.

\section{CONCLUSIONS}

The 26 indicators proposed to compose an index for the assessment of UA sustainability were inspired by the scientific and technical literature on urban sustainability. These indicators were grouped according to five categories of analysis, and also separated into sub-categories. These categories were defined according to the dimension of the food-energy-water-land/ space-air pollution Nexus. They all met the criteria of being measurable, sensitive to stress, predictable, anticipatory, controllable, integrative, responsive and stable. 
The index should show, on a scale ranging from zero to one, the degree to which the UA practiced by a city fulfils the sustainability criteria and targets set by 2030 UN SDGs. The next step in this research will involve validation of these indicators and determination of the weight of each indicator, to be defined via an Analytic Hierarchy Process, with the support of specialists, according to the criteria of the Delphi methodology. Through the attribution of weights, normalization and distance in relation to pre-established targets, improvements or reductions in the set of 26 indicators could support decision makers and public administrators in identifying and implementing corrective actions towards sustainable development.

\section{REFERENCES}

[1] Sanyé-Mengual, E., COST Action Urban Agriculture Europe: Freelance STSM: Stakeholders' Acceptance, Governance and Power Relations in Innovative Forms of Urban Agriculture, Muncheberg, Germany, 2015. https://doi.org/https://doi.org/10.13140/RG.2.1.2659.4966.

[2] UN DESA, Sustainable development goals report 2018. United Nations Department of Economic and Social Affair: New York, 2018.

[3] Hoff, H., Understanding the Nexus. Background paper for the Bonn2011 Nexus Conference, Stockholm Environment Institute, (Nov.), pp. 1-52, 2011.

[4] Allouche, J., Middleton, C. \& Gyawali, D., Technical veil, hidden politics: Interrogating the power linkages behind the nexus. Water Alternatives, 8(1), pp. 610626, 2015.

[5] Pintér, L., Hardi, P., Martinuzzi, A. \& Hall, J., Bellagio STAMP: Principles for sustainability assessment and measurement. Ecological Indicators, 17, pp. 20-28, 2012. https://doi.org/10.1016/j.ecolind.2011.07.001.

[6] Turnhout, E., Hisschemöller, M. \& Eijsackers, H., Ecological indicators: Between the two fires of science and policy. Ecological Indicators, 7(2), pp. 215-228, 2007. https://doi.org/10.1016/j.ecolind.2005.12.003.

[7] Dizdaroglu, D., Developing micro-level urban ecosystem indicators for sustainability assessment. Environmental Impact Assessment Review, 54, pp. 119-124, 2015. https://doi.org/10.1016/j.eiar.2015.06.004.

[8] Peng, J., Liu, Z., Liu, Y., Hu, X. \& Wang, A., Multifunctionality assessment of urban agriculture in Beijing City, China. Science of the Total Environment, 537, pp. 343351, 2015. https://doi.org/10.1016/j.scitotenv.2015.07.136.

[9] Grewal, S.S. \& Grewal, P.S., Can cities become self-reliant in food? Cities, 29(1), pp. 1-11, 2012. https://doi.org/10.1016/j.cities.2011.06.003.

[10] Saha, M. \& Eckelman, M.J., Growing fresh fruits and vegetables in an urban landscape: A geospatial assessment of ground level and rooftop urban agriculture potential in Boston, USA. Landscape and Urban Planning, 165(August 2016), pp. 130-141, 2017. https://doi.org/10.1016/j.landurbplan.2017.04.015.

[11] Orsini, F. et al., Exploring the production capacity of rooftop gardens (RTGs) in urban agriculture: the potential impact on food and nutrition security, biodiversity and other ecosystem services in the city of Bologna. Food Security, 6(6), pp. 781-792, 2014. https://doi.org/10.1007/s12571-014-0389-6.

[12] European Commission, European Commission's Directorate-General Environment, Depth report: Indicators for sustainable cities. UWE: Bristol, 2015. https://doi.org/10.2779/61700.

[13] Santini, G., Miller, S. \& Dubbeling, M., City Region Food System Tools/Examples City Region Food System Tools/Examples, FAO: Rome, 2018. www.fao.org/documents/ card/en/c/I9255EN. Accessed on: 21 Feb. 2020. 
[14] FAO/MUFPP/RUAF, The Milan Urban Food Policy Pact Monitoring Framework, Rome, 2019. www.milanurbanfoodpolicypact.org/wp-content/uploads/2019/11/ CA6144EN.pdf. Accessed on: 21 Feb. 2020.

[15] Zurek, M. et al., Sustainability metrics for the EU food system: A review across economic, environmental and social considerations, 2017.

https://susfans.eu/system/files/public_files/Publications/Reports/SUSFANS-

Deliverable-D1.3-UOXF.pdf. Accessed on: 21 Feb. 2020.

[16] van Leeuwen, C.J., Frijns, J., van Wezel, A. \& van de Ven, F.H.M., City Blueprints: 24 indicators to assess the sustainability of the urban water cycle. Water Resources Management, 26(8), pp. 2177-2197, 2012. https://doi.org/10.1007/s11269-012-0009-1.

[17] Koop, S.H.A. \& van Leeuwen, C.J., Assessment of the sustainability of water resources management: A critical review of the city blueprint approach. Water Resources Management, 29(15), pp. 5649-5670, 2015. https://doi.org/10.1007/s11269-015-1139-z.

[18] Economist Intelligence Unit, European Green City Index. Siemens AG: Munich, p. 51, 2009.

[19] University of Toronto, Global cities. List of indicators: Global city indicators facility 2007. http://www.globalcitiesinstitute.org. Accessed on: 21 Feb. 2020.

[20] ISO/TC 268, ISO 37120 - Sustainable development of communities, Indicators for city services and quality of life, 2014.

[21] Canadian International Development Agency (CIDA), Indicators for Sustainability How cities are monitoring and evaluating their success. Canada, 2012.

[22] Van Dijken, K., Dorenbos, R. \& Kamphof, R., The Reference Framework for Sustainable Cities (RFSC) Testing Results and Recommendations, The Hague, The Netherlands, 2012. https://www.eukn.eu/fileadmin/Lib/files/EUKN/2013/Finalreport NicistestingRFSC.pdf. Accessed on: 21 Feb. 2020.

[23] Star Community, Sustainability Tools for Assessing and Rating Communities (STAR) Community Rating System Version 2.0. http://www.starcommunities.org. Accessed on: 21 Feb. 2020.

[24] Berrini, M. \& Bono, L., Report 2007 urban ecosystem Europe: An integrated assessment on the sustainability of 32 European cities. Milan, Italy, 2007.

[25] Minx, J., Creutzig, F., Ziegler, T. \& Owen, A., Developing a pragmatic approach to assess urban metabolism in Europe - A report to the Environment Agency prepared by Technische Universität Berlin and Stockholm Environment Institute, Climatecon Working Paper 01/2011, Technische Universität Berlin: Berlin, Vol. 240, 2011.

[26] Mega, V. \& Pedersen, J., Urban Sustainability Indicators. European Foundation, Luxembourg, 1998. https://doi.org/10.18848/1832-2077/cgp/v07i06/55007.

[27] UN-Habitat, Urban Indicators Guidelines - UN-Habitat, 2004.

[28] Zhang, P. et al., Food-energy-water (FEW) nexus for urban sustainability: A comprehensive review. Resources, Conservation and Recycling, 142(Nov. 2018), pp. 215-224, 2019. https://doi.org/10.1016/j.resconrec.2018.11.018.

[29] Ringler, C., Bhaduri, A. \& Lawford, R., The nexus across water, energy, land and food (WELF): Potential for improved resource use efficiency? Current Opinion in Environmental Sustainability, 5(6), pp. 617-624, 2013. https://doi.org/10.1016/j.cosust.2013.11.002. 
[30] Karabulut, A.A., Crenna, E., Sala, S. \& Udias, A., A proposal for integration of the ecosystem-water-food-land-energy (EWFLE) nexus concept into life cycle assessment: A synthesis matrix system for food security. Journal of Cleaner Production, 172, pp. 3874-3889, 2018. https://doi.org/10.1016/j.jclepro.2017.05.092.

[31] Kumar, P. \& Saroj, D.P., Water-energy-pollution nexus for growing cities. Urban Climate, 10(P5), pp. 846-853, 2014. https://doi.org/10.1016/j.uclim.2014.07.004.

[32] Dale, V.H. \& Beyeler, S.C., Challenges in the development and use of ecological indicators. Ecological Indicators, 1(1), pp. 3-10, 2001. https://doi.org/10.1016/S1470-160X(01)00003-6.

[33] Lin, T., Lin, J., Cui, Y., Hui, S. \& Cameron, S., Using a network framework to quantitatively select ecological indicators. Ecological Indicators, 9(6), pp. 1114-1120, 2009. https://doi.org/10.1016/j.ecolind.2008.12.009.

[34] Willett, W. et al., Food in the Anthropocene: the EAT-Lancet Commission on healthy diets from sustainable food systems. Lancet, 6736, pp. 3-49, 2019. https://doi.org/10.1016/S0140-6736(18)31788-4.

[35] Moran, D.D., Wackernagel, M., Kitzes, J.A., Goldfinger, S.H. \& Boutaud, A., Measuring sustainable development - Nation by nation. Ecological Economics, 64(3), pp. 470-474, 2008. https://doi.org/10.1016/j.ecolecon.2007.08.017.

[36] Orsini, F., Kahane, R., Nono-Womdim, R. \& Gianquinto, G., Urban agriculture in the developing world: A review. Agronomy for Sustainable Development, 33(4), pp. 695720, 2013. https://doi.org/10.1007/s13593-013-0143-z.

[37] Song, T., Cai, J., Chahine, T. \& Li, L., Towards smart cities by Internet of Things (IoT) - a Silent Revolution in China. Journal of the Knowledge Economy, 2017. https://doi.org/https://doi.org/10.1007/s13132-017-0493-x.

[38] Nchanji, E.B. et al., Assessing the sustainability of vegetable production practices in northern Ghana*. International Journal of Agricultural Sustainability, 15(3), pp. 321337, 2017. https://doi.org/10.1080/14735903.2017.1312796.

[39] Gerster-Bentaya, M., Nutrition-sensitive urban agriculture. Food Security, 5(5), pp. 723-737, 2013. https://doi.org/10.1007/s12571-013-0295-3.

[40] Borges, C.A., Cabral-Miranda, W. \& Jaime, P.C., Urban food sources and the challenges of food availability according to the Brazilian dietary guidelines recommendations. Sustainability (Switzerland), 10(12), 2018. https://doi.org/10.3390/su10124643.

[41] Schnell, S.M., Food miles, local eating, and community supported agriculture: Putting local food in its place. Agriculture and Human Values, 30(4), pp. 615-628, 2013. https://doi.org/10.1007/s10460-013-9436-8.

[42] Eigenbrod, C. \& Gruda, N., Urban vegetable for food security in cities. A review. Agronomy for Sustainable Development, 35(2), pp. 483-498, 2015. https://doi.org/10.1007/s13593-014-0273-y

[43] Goldstein, B., Hauschild, M., Fernández, J. \& Birkved, M., Testing the environmental performance of urban agriculture as a food supply in northern climates. Journal of Cleaner Production, 135, pp. 984-994, 2016. https://doi.org/10.1016/j.jclepro.2016.07.004.

[44] Riahi, K. et al., The Shared Socioeconomic Pathways and their energy, land use, and greenhouse gas emissions implications: An overview. Global Environmental Change, 42, pp. 153-168, 2017. https://doi.org/10.1016/j.gloenvcha.2016.05.009. 
[45] IPCC, Summary for policymakers. IPCC Fifth Assessment Report: Working Group III Mitigation of Climate Change, eds T.Z. Edenhofer et al., Cambridge University Press: Cambridge, UK, and New York, pp. 1-33, 2014. https://doi.org/10.1017/CBO9781107415324

[46] Lupia, F., Baiocchi, V., Lelo, K. \& Pulighe, G., Exploring rooftop rainwater harvesting potential for food production in urban areas. Agriculture (Switzerland), 7(6), 2017. https://doi.org/10.3390/agriculture7060046.

[47] Paviotti-Fischer, E., Lopes-Torres, E.J., Santos, M.A.J., Brandolini, S.V.P.B. \& Pinheiro, J., Xiphidiocercariae from naturally infected Lymnaea columella (Mollusca, Gastropoda) in urban area: Morphology and ultrastructure of the larvae and histological changes in the mollusc host. Brazilian Journal of Biology, 79(3), pp. 446451, 2019. https://doi.org/10.1590/1519-6984.182501.

[48] Kumar, K., \& Hundal, L.S., Soil in the city: Sustainably improving urban soils. Journal of Environmental Quality, 45(1), pp. 2-8, 2016. https://doi.org/10.2134/jeq2015.11.0589.

[49] Lin, B.B., Philpott, S.M. \& Jha, S., The future of urban agriculture and biodiversityecosystem services: Challenges and next steps. Basic and Applied Ecology, 16(3), pp. 189-201, 2015. https://doi.org/10.1016/j.baae.2015.01.005.

[50] Brown, K.H. \& Jameton, A.L., Public health implications of urban agriculture. Journal of Public Health Policy, 21(1), pp. 20-39, 2000. https://doi.org/10.2307/3343472.

[51] Brown, S.L., Chaney, R.L. \& Hettiarachchi, G.M., Lead in urban soils: A real or perceived concern for urban agriculture? Journal of Environmental Quality, 45(1), pp. 26-36, 2016. https://doi.org/10.2134/jeq2015.07.0376.

[52] Drechsel, P. \& Dongus, S., Dynamics and sustainability of urban agriculture: Examples from sub-Saharan Africa. Sustainability Science, 5(1), pp. 69-78, 2010. https://doi.org/10.1007/s11625-009-0097-x.

[53] Yates, J.S. \& Gutberlet, J., Reclaiming and recirculating urban natures: Integrated organic waste management in Diadema, Brazil. Environment and Planning A, 43(9), pp. 2109-2124, 2011. https://doi.org/10.1068/a4439.

[54] Amato-Lourenco, L.F. et al., The influence of atmospheric particles on the elemental content of vegetables in urban gardens of Sao Paulo, Brazil. Environmental Pollution, 216, pp. 125-134, 2016. https://doi.org/10.1016/j.envpol.2016.05.036. 